\title{
The Effects of Neoliberal Wind Power Policies on Rural Areas in Turkey: The Case of Izmir
}

\section{Zeynep Özçam*}

\begin{abstract}
As a result of the rising global concerns about environmental crisis, transition to low carbon energy systems has gained great importance around the world. Renewable energy types, wind power in particular, have begun to be seen as an effective tool of such transition. In Turkey, too, wind power policies have gained prominence, with an increase in central government's support of investments. Investors began to choose locations with high wind power potential in the rural peripheries primarily of Turkey's western provinces. In this sense, Izmir's periphery appears as one of the important targets of large-scale wind power investments. However, despite the consensus on the necessity of transition from fossil fuels to renewables, discontent began to arise as a consequence of the installation of wind power plants in the proximity to local settlements. Some of the socio-economic consequences of the transitional process in rural areas, including the expropriation of agricultural land and dispossession, generate remarkable tensions at local level. This study aims to understand how the wind power policies in Turkey have been shaped by the global and national neoliberal policies and to reveal the consequences of these policies at local level, especially in rural areas. The tensions that wind power developments bring about in the rural landscape are examined through a case study of Izmir and its rural periphery. In this context, this paper critically reviews the neoliberal energy policies in Turkey and tries to reveal the socio-economic outcomes of these energy policies by analyzing the dynamics of energy generation, distribution and consumption, which are closely related to neoliberal governance and urbanization practices.
\end{abstract}

Keywords: Neoliberal energy policies, wind power policies, rural periphery, neoliberal governance, Izmir

\section{Özet}

Türkiye'de Neoliberal Rüzgâr Enerjisi Politikalarının Kırsal Alanlar Üzerindeki Etkileri: İzmir Örneği

Tüm dünyada, çevresel krizle ilgili küresel endişeler sonucunda düşük karbonlu enerji sistemlerine geçiş büyük önem kazanmıștır. Yenilenebilir enerjiler ve özellikle rüzgâr enerjisi, bu anlamda etkili bir araç olarak görülmeye başlanmıştır. Aynı şekilde Türkiye'de rüzgâr enerjisi politikaları ön plana çıkmış, ulusal hükümetin desteklediği yatırımlar artmaya başlamış ve bu yatırımlar özellikle Türkiye'nin batı illeri başta olmak üzere rüzgâr potansiyeli yüksek kırsal alanlardan yer seçmeye başlamıştır. Bu bağlamda, İzmir'in çeperinin, büyük ölçekli rüzgâr enerijisi yatırımlarının önemli hedeflerinden biri haline geldiği gözlemlenmektedir. Ancak, fosil yakıtlardan yenilenebilir enerjiye geçişin gerekliliği konusundaki genel kabule rağmen, yenilenebilir enerji santrallerinin yaşam alanlarına yakın bölgelerde inşa edilmesi sonucu karşıtlıklar ortaya çıkmaya başlamıştır. Bu geçiş süreçleri, kırsal alanlarda tarım arazilerinin kamulaştırılması ve mülksüzleștirilme gibi bazı sosyo-ekonomik sonuçlara neden olmakta ve yerel düzeyde dikkate değer gerilimler yaratmaktadır. Bu çalışmanın amacı, Türkiye'de rüzgâr enerjisi yatırımlarının, global ve ulusal neoliberal politikalar çerçevesinde nasıl şekillendiğini anlamak ve bu politikaların yerelde, özellikle kırsal alanlar üzerinde ne tür sonuçlar doğurduğunu ortaya koymaktır. Türkiye'deki kırsal alanlardaki rüzgar enerjisi gelişmelerinin neden olduğu gerilimler, İzmir ve kırsal çevresi üzerinden analiz edilmiştir. Bu bağlamda, makale Türkiye'deki neoliberal enerji politikalarını eleştirel bir biçimde göz-

* Izmir Institute of Technology, Department of City and Regional Planning 
den geçirmekte ve bu enerji politikalarının sosyo-ekonomik sonuçlarını, neoliberal yönetim ve kentleşme uygulamalarıyla yakından ilgili olan enerji üretimi, dağıtımı ve tüketimi dinamiklerini analiz ederek ortaya koymaya çalışmaktadır.

Anahtar sözcükler: Neoliberal enerji politikaları, rüzgâr enerjisi politikaları, kırsal çeper, neoliberal yönetim, İzmir

\section{Introduction}

Renewable energies are regarded as an efficient tool to solve social and environmental problems, among them the rising energy-hunger of highly urbanized world and the challenges of anthropogenic climate change are significant. The energy demand of densely populated urban cores and their "high energy society" are expected to grow further as the urban areas are growing in terms of economy and population. The renewables in this sense are widely recognized as an effective tool to limit energy-related emissions released in energy supply for urban areas. Thus, they are regarded as a fundamental component of sustainable development of cities. ${ }^{1}$ In this sense, wind power has considerable place since it is regarded to be a great source of low-carbon electricity as a large-scale and affordable alternative of energy provision. ${ }^{2}$ However, as wind power plants are large-scale in size, their installation needs vast and vacant lands. For that reason, they choose location in rural and natural areas. Under these circumstances, oppositions began to arise as soon as wind power plants are constructed in the proximity to the naturally important areas and rural settlements. ${ }^{3}$

A similar problem began to grow in Turkey, following the increase in political and economic interest for wind power market. Central government's interest in wind power increases along with the concerns related to domestic energy provision and foreign dependency on energy. These concerns were seen legitimate enough to accelerate wind power market in energy sector. Moreover, supranational organizations also promote renewable energy market creation in Turkey through supports such as climate adaptation and mitigation aid. ${ }^{4}$ As a result, the investments have accelerated by the help of national and international incentive systems and installations started to spread especially around the rural hinterlands of Turkey's western provinces. Eventually, wind power has grown approximately by 30\% each year since 2008 and the city of Izmir appears to be one of the important targets of large-scale national wind energy investments; it became the city where the highest rate of wind power invest-

1 Ibrahim Dincer, "Renewable Energy and Sustainable Development: A Crucial Review," Renewable and Sustainable Energy Reviews 4, no. 2 (June 2000): 157-175.

2 Paul Gipe, Wind Energy Comes of Age, vol. 4 (John Wiley \& Sons, 1995).

3 David Toke, Sylvia Breukers, and Maarten Wolsink, “Wind Power Deployment Outcomes: How Can We Account for the Differences?" Renewable and Sustainable Energy Reviews 12, no. 4 (May 2008): 1129-1147.

4 The Organisation for Economic Co-operation and Development (OECD), Development Cooperation Report 2017: Data for Development (OECD Publishing, 2018), accessed January 2018, http://www.oecd.org/dac/stats/turkeys-official-development-assistanceoda.htm. 
ments have taken place. ${ }^{5}$ The rural periphery of Izmir has been exposed to great pressures of wind power investments because of having available sites for development with high wind potential. However, large-scale deployment of wind power plants has soon begun to lead to some socio-economic outcomes in these rural areas such as expropriation and dispossession of agricultural lands. Such outcomes started to generate some tensions at local level and led to local opposition. Yet, local oppositions have arisen in the form of protests and legal actions in order to protect local living environments from the detrimental effects of large-scale energy investments.

The main aim of this study is to address these tensions between wind power policies and rural landscapes through a critical review of neoliberal energy policies in Turkey. The socio-economic outcomes of these energy policies will be revealed by analyzing the dynamics of energy generation, distribution and consumption, which are closely related to neoliberal governance practices and urbanization practices.

In this framework, the paper firstly introduces an understanding of the neoliberal energy policies and wind power in the world. After that, the paper focuses on the low-carbon energy policies of Turkey. Following this, the infusion of energy developments into rural landscapes is examined and the socio-economic consequences of this infusion are discussed with special emphasis on the Izmir case and the aroused tensions.

\section{Energy Policies in the Neoliberal Era}

Due to the development of industry and the fast increment of urbanization, the need for energy has rapidly increased in the last few decades. ${ }^{6}$ Energy consumption - so as energy supply, has nearly doubled between 1970s and 2013.7 The source of this energy is carbon-intensive fossil fuels, the usage of which leads to a major threat called global warming. As a result, "carbon control" has become a primary objective of recent political and economic governance at urban, regional and global scales, ${ }^{8}$ which requires developing new ways - and new geographies - of producing, living, and working with energy. ${ }^{9}$

5 Turkish Wind Energy Association (TWEA). Turkish Wind Energy Statistics Report- July 2018 (Ankara: Turkish Wind Energy Association, 2017), accessed December 2018, https://www. tureb.com.tr/files/tureb_sayfa/duyurular/2018/08/istatistik_raporu_temmuz_2018.pdf.

6 Bulent Yaniktepe, M. Mustafa Savrun, and Tahsin Koroglu, “Current Status of Wind Energy and Wind Energy Policy in Turkey," Energy Conversion and Management 72 (August 2013): 103-110.

7 International Energy Agency (IEA), Key Trends in CO2 Emissions. Excerpt from: CO2 Emissions from Fuel Combustion (Paris: International Energy Agency, 2015), accessed January 2018, www.iea.org/publications/freepublications/publication/CO2 EmissionsTrends.pdf.

8 Gavin Bridge, "Resource Geographies 1: Making Carbon Economies, Old and New," Progress in Human Geography 35, no. 6 (2011): 820-834.

9 Gavin Bridge, Stefan Bouzarovski, Michael Bradshaw, and Nick Eyre, "Geographies of Energy Transition: Space, Place and the Low-Carbon Economy," Energy Policy 53 (February 2013): 331-340. 
Following these global concerns about environmental crisis related to fast urbanization and supreme energy consumption, environmental policies have been put on the agenda all over the world. ${ }^{10}$ In these global environmental policies, the transitions to low-carbon energy systems have been promoted. Especially after the International Conference for Renewable Energy held in Bonn, Germany in 2004, ${ }^{11}$ political support for renewable energy has increased at both national and supranational levels. After Bonn, there has been growing interest by the World Bank and other multilateral development banks in renewable energy deployment in both developed and developing countries. ${ }^{12}$ Moreover, besides the governments, several global environmental NGOs started to give great support to renewables. ${ }^{13}$ As a result of this global and national backing for renewables, the investments in low-carbon technologies have significantly increased in the world, reaching to the rate of 43\% from 2004 to 2015. Among these renewables, wind power has the most remarkable growth with the rate of $90 \%$ during the same period. ${ }^{14}$

Along with these legitimate environmental concerns, the expansion in wind power deployments is substantially linked to the neoliberal government policies. Neoliberal period refers to a period of market-led regulatory restructuring aiming at the deregulation of economy towards more private-oriented capitalist profit-making. The deregulation also includes the reduction of the role of state under the conditions of advanced contemporary capitalism. ${ }^{15}$ Albeit in recent years, especially under the neoliberal state-restructuring of roll-out phase $\mathrm{e}^{16}$ the regulation of the economy through state intervention that promote and encourage large-scale projects has intensified..$^{17}$ In this context, the capitalist interventions have extended through commodification of all fields of services for opening up new arenas for profit-making. The process of marketization and commodification are now mediated directly by state institutions by a variety of policy arenas. ${ }^{18}$ One of those policies can be regarded as large-scale infrastructure provision and the renewable energy deployment as a part of it. Thus,

10 İlhan Tekeli and Anlı Ataöv, Sürdürülebilir Toplum ve Yapılı Çevre - Stratejiler Yelpazesi (İstanbul: İstanbul Bilgi Üniversitesi Yayınları, 2017).

11 "Bonn International Conference for Renewable Energy", REN21, accessed June 2018, https:// www.ren21.net/events/irecs/.

12 "Renewable Energy Fund for Africa", World Bank, accessed January 2018, http://projects. worldbank.org/P160699?lang=en.

13 The most known ones are WWF and Greenpeace.

14 "Statistics", International Energy Agency, accessed January 2018, http://www.iea.org/ statistics/statisticssearch/.

15 Neil Brenner, “Urban Governance and the Production of New State Spaces in Western Europe, 1960-2000," Review of International Political Economy 11, no. 3 (2004): 447-488.

16 Roger Keil, “The Urban Politics of Roll-With-It Neoliberalization," City 13, no. 2-3 (2009): 230-245.

17 Mustafa Kemal Bayırbağ and Mehmet Penpecioğlu, "Urban Crisis: 'Limits to Governance of Alienation'," Urban Studies 54, no. 9 (2017): 2056-2071.

18 Brenner, "Urban Governance". 
renewables started to be supported by national agendas as they provide new market for inviting global financial capital to invest into large-scale energy projects and create new opportunities for investment. ${ }^{19}$

Cities are regarded as growth machines from the political economy perspective $^{20}$ and under the neoliberal restructuring, urban cores have become the main sites for the states' economic intervention. Until this time, public investments including infrastructure and service provisions as well as private investments were agglomerated in urban areas, while rural peripheries were neglected. ${ }^{21}$ Albeit recently, not only urban but also rural areas have been affected by those economic interventions. In this sense, rural hinterlands as well as urban centers started to be seen as motors of economic growth. ${ }^{22}$ They become profit-making assets, privatization of which can provide new sites for capital accumulation. Recently, the countryside started to be affected from large-scale infrastructural developments, which are increased as a result of the attempts in favor of privatization and liberalization. ${ }^{23}$ Through privatization of large-scale energy provision systems, investments in renewable energy have increased and started to infuse into rural areas in different countries in the world such as Germany, Spain and the United Kingdom. ${ }^{24}$

Additionally, all these processes are closely related with the inter-scalar levels of support for low-carbon energy transition. Over the past few decades, inter-governmental policies tackling with environmental crisis and its socio-economic outcomes started to have significant influence on the institutional reforms of national governments and their political economies. There is a renewed support with international policies at global scale for sustainable development of cities in the context of global environmental and economic crises. ${ }^{25}$ Among these policies, promotion of renewable energy has a remarkable place, since those are considered as carbon-free energy sources as opposed to carbon-intensive conventional resources.

In this regard, low-carbon energy transition in urban energy infrastructure through renewable energy deployment has been prominent in recent years. This is substantially related with the significant role that cities and urban infra-

19 Neil Brenner, “Theses on Urbanization," Public Culture 25, no. 1 (69) (2013): 85-114.

20 Harvey Molotch,“The Political Economy of Growth Machines,” Journal of Urban Affairs 15, no. 1 (March 1993): 29-53.

21 Matthias Naumann and Anja Reichert-Schick, "Infrastructure and Peripheralization: Empirical Evidence from North-Eastern Germany," in Peripheralization, ed. A. Fischer-Tahir and M. Naumann (Wiesbaden: Springer VS, 2013), 145-167.

22 Kaj Zimmerbauer and Anssi Paasi, "When Old and New Regionalism Collide: Deinstitutionalization of Regions and Resistance Identity in Municipality Amalgamations," Journal of Rural Studies 30 (April 2013): 31-40.

23 Brenner, "Urban Governance".

24 Toke et al., "Wind Power Deployment Outcomes".

25 Connor Joseph Cavanagh and Tor Arve Benjaminsen, "Political Ecology, Variegated Green Economies, and the Foreclosure of Alternative Sustainabilities," Journal of Political Ecology Special Section: Political Ecologies of the Green Economy 24, no. 1 (2017): 200-216. 
structural networks play in energy consumption and energy-related emissions. The cities in the world occupy only 3\% of the Earth's land, but account for $80 \%$ of energy consumption and 75\% of carbon emissions. ${ }^{26}$ The energy use is mainly determined by the anthropogenic activities many of which are concentrated in urban areas. In IEA news published in 2017, ${ }^{27}$ the key sectors for tracking energy consumption are defined as transport, services, manufacturing and housing, all of which are essentially urban sectors (See Figure 1). According to the IEA data, the transport sector accounted for the highest share of final energy consumption (34\%), followed by the manufacturing industry (27\%), housing (19\%) and finally the services sector (14\%). Accordingly, cities become potentially important sites for political action around energy transition ${ }^{28}$ so that they become important sites for renewable energy generation and market creation.

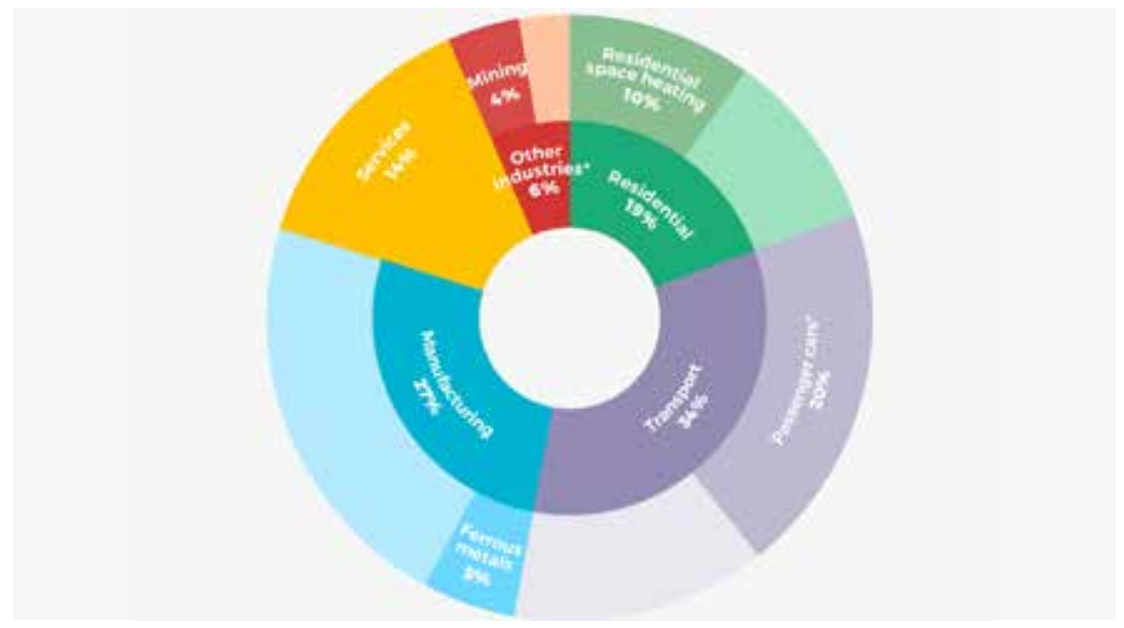

Figure 1: Largest energy uses in urban areas in IEA countries (Source: Produced with the data from IEA, 2017)

Under these circumstances, the leading international policy makers such as $\mathrm{UN}$ and EU have taken steps to strengthen sustainable, low-carbon transition of urban areas. ${ }^{29}$ Among these global scale interventions, the Kyoto Protocol (entered into force in 2005), EU Sustainable Development Strategy (adopted in 2009), RIO +20 Conference (held in 2012) and Paris Agreement (adopted in 2015) are the most important ones. These political attempts legally bind the involved par-

26 "The Sustainable Development Agenda", United Nations, accessed June 2018, https://www. un.org/sustainabledevelopment/development-agenda/.

27 "The IEA Energy Efficiency Indicators Database", International Energy Agency (IEA), accessed January 2018, https://www.iea.org/newsroom/news/2017/december/the-ieaenergy-efficiency-indicators-database.html.

28 Bridge et al., "Geographies of Energy Transition".

29 Tekeli and Ataöv, Sürdürülebilir Toplum ve Yapılı Çevre - Stratejiler Yelpazesi. 
ties to set emission reduction targets in their countries and led to political action to implement practical measures for sustainable development and low-carbon transition. They all introduced groundbreaking guidelines on green economy policies with an emphasis on investments in low-carbon energy technologies to achieve the targets on the reduction of energy related emissions. ${ }^{30}$ Besides, the resolutions of the International Renewable Energy Conference held in Bonn in 2004, increased the importance of energy efficiency applications and renewable energy deployment.

With these positive policy moves and support mechanisms, the market for wind power has expanded; $40 \%$ of renewable based new power generation capacity in the world in 2015 was wind power. For future investments, wind power is expected to have a remarkable share. In the European Union, renewables account for $80 \%$ of new capacity and wind power becomes the leading source of electricity. ${ }^{31}$ China has the largest wind power market with the highest installed capacity in onshore in the world. The USA and Germany follow China in terms of total installed capacity. Turkey is ranked seventh among the top ten countries in the world in terms of new installed capacity. ${ }^{32}$

As the situation signifies, national political agendas started to support electricity generation from renewables. ${ }^{33}$ One reason for the national and international support for a shift in energy resources is the challenges brought by the conventional energy generation based on fossil fuels. The other reason is the creation of new markets for economic growth in many countries. Climate policies in favor of renewables may reduce emissions and mitigate the threats of climate change, but at the same time they provide new sites for investment. Hence, governments are expected to support and stimulate renewable energy market creation with regulatory arrangements and incentive mechanisms. ${ }^{34}$ Emission policies create new markets around which firms can develop economic strategies and create new sites for investment ${ }^{35}$ through commodification and privatization of nature. ${ }^{36}$ Renewables are a part of these policies and an important tool for new mode of capital accumulation in the existing capitalist order. Global

30 "United Nations Sustainable Development", United Nations, accessed June 2018, http:// www.un.org/sustainabledevelopment/; "European Commission Sustainable Development", European Commission, accessed June 2018, http://ec.europa.eu/environment/eussd/.

31 International Energy Agency (IEA), “Statistics”.

32 Global Wind Energy Council (GWEC). Global Wind Report- 2016. (Brussels: Global Wind Energy Association, 2016), accessed January 2018, http://www.gwec.net/wp-content/ uploads/2017/05/Global-Status-2016.pdf.

33 Joyce McLaren Loring, "Wind Energy Planning in England, Wales and Denmark: Factors Influencing Project Success," Energy Policy 35, no. 4 (April 2007): 2648-2660.

34 Buket Atlı, “Politics of Renewable Energy Policies in Turkey”(Master's Thesis, German Turkish Masters in Social Sciences Humboldt Universität zu Berlin and Middle East Technical University, 2012).

35 Karine Matthews and Matthew Paterson, "Boom or Bust? The Economic Engine Behind the Drive for Climate Change Policy," Global Change, Peace \& Security 17, no. 1 (2005): 59-75.

36 Cavanagh and Benjaminsen, "Political Ecology, Variegated Green Economies". 
ecological concerns provide this neoliberal move with legitimacy.

This transition fuelled by neoliberal energy policies started to have spatial impacts on urban areas and their hinterlands as energy systems are constituted spatially. The components of the energy systems are embedded in particular localities, but their networked nature produces geographies of connection and dependency. ${ }^{37}$ The low-carbon energy investments have been located at the rural periphery as rural areas provide suitable sites for those investments. The energy produced at rural periphery have been transferred to urban cores via networked nature of the system to be consumed by urban populations; which makes a new rural-urban connection and dependency in contemporary urbanization trends.

The low-carbon energy transition via wind energy deployment at rural hinterlands has produced wind power landscapes over rural landscapes together with the land-use change from agriculture to energy fields. The change caused by this transition has created some tensions and conflicts at local level ${ }^{38}$ in different parts of the world, including European countries such as Spain, Germany, and Denmark ${ }^{39}$ as well as Turkey. The key issue in these tensions is that, regardless of being environmentally friendly, wind power developments, which can be considered as infrastructural developments, have been rapidly spreading in natural and agricultural areas. The wind turbines are perceived as foreign structures and the change resulted by their intrusion into the rural landscape has led to significant concerns regarding the local communities' living environments. ${ }^{40}$ Furthermore, the impact of this specific development has been perceived as a disruption of place attachment or as a threat to place identity. ${ }^{41}$ People, who have a positive sense of identity related to a particular landscape (e.g. rural landscape), are more likely to oppose such developments. ${ }^{42}$ If the local living environment is in danger of disruption, oppositions emerge with the intention to protect local environment, which can be described as place-protective actions, and attempts to cope with a change resulted by the specific development. ${ }^{43}$

37 Bridge et al., "Geographies of Energy Transition”.

38 Michael Woods, "Conflicting Environmental Visions of the Rural: Windfarm Development in Mid Wales," Sociologia Ruralis 43, no. 3 (July 2003): 271-288.

39 Toke et al., "Wind Power Deployment Outcomes".

40 Maarten Wolsink, "Planning of Renewables Schemes: Deliberative and Fair Decision-Making on Landscape Issues Instead of Reproachful Accusations of Non-Cooperation," Energy Policy 35, no. 5 (May 2007): 2692-2704.

41 Patrick Devine-Wright, "Rethinking NIMBYism: The Role of Place Attachment and Place Identity in Explaining Place-Protective Action," Journal of Community EApplied Social Psychology 19, no. 6 (November-December 2009): 426-441.

42 Dan Van der Horst, "NIMBY or Not? Exploring the Relevance of Location and the Politics of Voiced Opinions in Renewable Energy Siting Controversies," Energy Policy 35, no. 5 (May 2007): 2705-2714.

43 Devine-Wright, "Rethinking NIMBYism”. 


\section{Low-Carbon Energy Policies in Turkey}

Among the Turkey's energy related concerns, ensuring sufficient energy supply for a growing economy and population, and reducing foreign dependency on energy have been the most important matters. Current primary energy demand of Turkey, which is high and likely to increase by $80 \%$ until $2023,{ }^{44}$ is met from various sources but the primary sources are natural gas, coal and oil. The share of these fossil fuels amounts to $90 \%$ of the total volume of energy consumption. ${ }^{45}$ Besides, the demand of electricity, the main determinant of Turkey's energy demand, is also growing fast. Electricity consumption has nearly doubled from the year 2000 to date and the electricity demand is projected to double again by the year 2023. Growing electricity demand has been mainly supplied by fossil fuels: natural gas has the highest share with $48 \%$ and coal is the second with the share of $26.5 \% .{ }^{46}$ However, as being not very rich in terms of natural resources, Turkey imports most of its energy supply, which makes the country foreign-dependent in terms of energy.

The energy system of Turkey is influenced by domestic and non-domestic forces. As being a party to the Kyoto Protocol, and being a candidate country to EU, Turkey's energy policies have been affected by the international energy policies, determined by those supranational structures. International agreements and European market liberalization are among the main forces that affect Turkey's national energy policies. Accordingly, both for achieving compliance with the policies of supranational structures and reducing foreign dependency on energy, renewable energy policies have accelerated in Turkey. Moreover, the renewable energy market creation in Turkey is supported internationally, through international funds including climate adaptation and mitigation aid provided by United Nations. ${ }^{47}$ In this context, Turkey have set determinant goals for electricity generation based on renewables for the year 2023, using the advantage of having high potential in low-carbon resources such as hydro, geothermal, wind and solar. Currently, the government aims to increase the share of renewables in electricity generation (together with hydroelectricity) to $30 \%$ by 2023 . Another aim is to raise the share of renewable energy in overall energy consumption

44 Ministry of Energy and Natural Resources (MENR), Turkey's National Renewable Energy Action Plan (Ankara: Ministry of Energy and Natural Resources, 2014), accessed December 2017, www.eie.gov.tr/duyurular_haberler/document/Turkiye_Ulusal_Yenilenebilir_Enerji_Eylem_Plani.pdf.

45 "Turkey's Energy Profile and Strategy", Ministry of Foreign Affairs (MFA), accessed January 2018, www.mfa.gov.tr/turkeys-energy-strategy.en.mfa.

46 "Electricity Market Production Licenses Database", Energy Market Regulatory Authority (EMRA), accessed June 2019, http://lisans.epdk.org.tr/epvys-web/faces/pages/lisans/ elektrikUretim/elektrikUretimOzetSorgula.xhtml.

47 The Organisation for Economic Co-operation and Development (OECD). Development Co-operation Report 2017: Data for Development. 
at least to $20 \%$ as of $2023 .{ }^{48}$ In this sense, increasing diversity and maximizing low-carbon resources in energy supply stand out as the key issues among the Turkey's energy strategies. These strategies have been facilitated through privatization of energy networks that enables the creation of new sites for private investment. $^{49}$

\section{The Intrusion of Energy Investments in Rural Landscapes}

Since the 1980s, the introduction of neoliberal policies has brought significant changes in urban development and planning all over the world as well as in Turkey. Especially the neoliberal policies after the 2000s, reshaped through new urban policy approach based on large-scale urban development projects have transformed the urban areas to a great extent. ${ }^{50}$ This type of neoliberal policy has paved the way for large-scale spatial projects, which have been mediated directly by the state with a variety of policy arenas focusing on spatial strategies. ${ }^{51}$ One of those projects, initiated by the state itself, is the infrastructure projects including large-scale energy developments.

Even though the spatial strategies have mainly targeted urban areas, rural areas too, have been affected by some of the large-scale infrastructural projects. The rural has been experiencing a peripheralization until very recently as a result of the agglomeration of services and activities on urban areas. ${ }^{52}$ Nevertheless, the rural is also under influence of the pressures stemming from large-scale spatial strategies of the national governments, since the rural peripheries started to be seen as potential sites for large-scale infrastructural developments. ${ }^{53}$ One of those pressures is exposed by large-scale wind power developments ${ }^{54}$ as discussed in this paper.

For Turkey, wind power emerges as one of the most significant components of energy strategies, because of being a favorable domestic resource and an important market for growing energy sector. The government of Turkey has given weight to wind power and supported the sector with special incentive systems and regulatory arrangements that increases competitive advantage of wind

48 Ministry of Energy and Natural Resources (MENR). Turkey's National Renewable Energy Action Plan.

49 Atll, "Politics of Renewable Energy Policies in Turkey".

50 Erik Swyngedouw, Frank Moulaert, and Arantxa Rodriguez, "Neoliberal Urbanization in Europe: Large-Scale Urban Development Projects and the New Urban Policy," Antipode 34, no. 3 (July 2002): 542-577.

51 Brenner, "Urban Governance and the Production of New State Spaces in Western Europe, 1960-2000".

52 Naumann and Reichert-Schick, “Infrastructure and Peripheralization: Empirical Evidence from North-Eastern Germany".

53 Woods, "Conflicting Environmental Visions of the Rural: Windfarm Development in Mid Wales".

54 Wolsink, "Planning of Renewables Schemes: Deliberative and Fair Decision-Making on Landscape Issues Instead of Reproachful Accusations of Non-Cooperation"; Van der Horst, "NIMBY or not? Exploring the Relevance of Location and the Politics of Voiced Opinions in Renewable Energy Siting Controversies". 
power over other investment models with the interest of promoting market growth. With the support from the government, large-scale investments have risen over the past few years. These developments have accelerated since 2006 with the positive policy moves and regulatory arrangements such as the Ninth Development Plan and the Renewable Energy Law (Law No: 5346) dated 2005. ${ }^{55}$ Consequently, state policies backing renewables and particularly wind power, have gained momentum so as to reduce energy-related problems as well as to create new market opportunities for economic growth.

As a consequence, wind power investments have increased considerably with the ratio of 30\% between the years 2015 and 2016. According to 2018 data, there are 171 wind power plants in operation, which are owned by major energy companies operating in energy and building sectors in Turkey. There are also 29 wind power plants under construction and 60 licensed wind power plants awaiting construction. The ones in operation are densely concentrated in the Mediterranean region. The licensed ones and the ones under construction have also chosen location in similar regions. ${ }^{56}$ This situation leads to an accumulation of energy investments over certain geographies (See Figure 2).

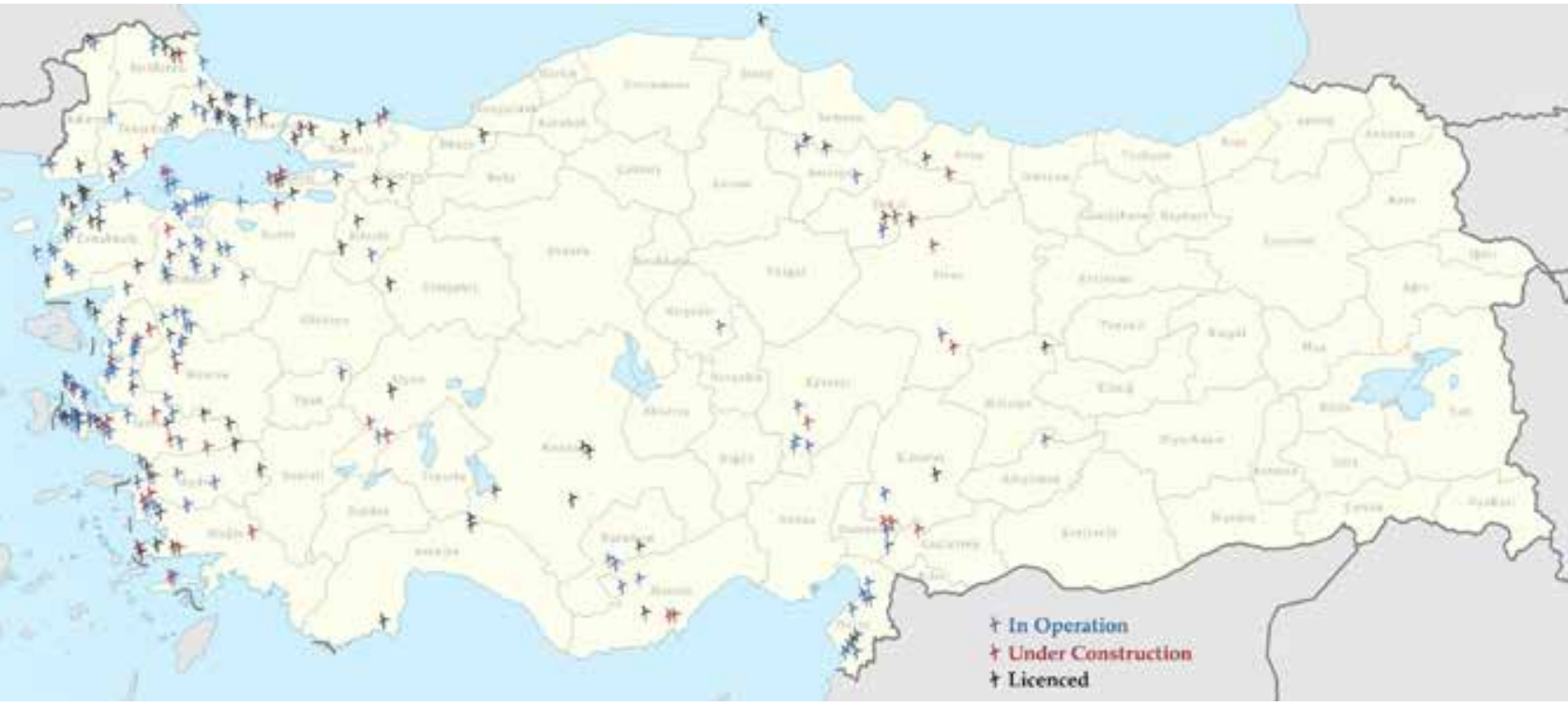

Figure 2: Wind power plants in Turkey

(Source: Produced with the data from TWEA, 2017)

Regarding the case of Izmir, the city has come to the fore as a favorable location for most of the wind power investments. It has become the city, where most of the investments have concentrated since $2008 .{ }^{57}$ All those wind power

55 Yaniktepe et al.,"Current Status of Wind Energy and Wind Energy Policy in Turkey”.

56 Turkish Wind Energy Association (TWEA). Turkish Wind Energy Statistics Report - July 2018.

57 Turkish Wind Energy Association (TWEA). Turkish Wind Energy Statistics Report - July 2018. 
investments have densely concentrated in Izmir's rural hinterland. Today, there are 42 wind power plants in Izmir, all located in the rural districts of the province (See Table 1).

\begin{tabular}{|c|c|c|c|c|}
\hline District & $\begin{array}{c}\text { \# of Wind } \\
\text { Power Plants }\end{array}$ & Condition & $\begin{array}{c}\text { Total Capacity } \\
\text { (MWe) }\end{array}$ & \# of Turbines \\
\hline ALİAĞA & 5 & In Operation & 193,9 & 83 \\
\hline BAYINDIR & 1 & $\begin{array}{c}\text { Under } \\
\text { Construction }\end{array}$ & 56,525 & 17 \\
\hline BERGAMA & 2 & In Operation & 94,95 & 29 \\
\hline ÇEŞME & 1 & $\begin{array}{c}\text { Under } \\
\text { Construction }\end{array}$ & 18 & 8 \\
\hline ÇEŞME & 5 & In Operation & 108,55 & 46 \\
\hline DİKİLI & 1 & In Operation & 4,8 & 2 \\
\hline GAZİEMİR & 1 & $\begin{array}{c}\text { Under } \\
\text { Construction }\end{array}$ & 20 & 10 \\
\hline KARABURUN & 1 & $\begin{array}{c}\text { Under } \\
\text { Construction }\end{array}$ & 105 & 1 \\
\hline KARABURUN & 6 & In Operation & 231,55 & 145 \\
\hline KEMALPAŞA & 3 & In Operation & 40 & 15 \\
\hline KINIK & 1 & In Operation & 50 & 17 \\
\hline KİAZZ & 1 & $\begin{array}{c}\text { Under } \\
\text { Construction }\end{array}$ & 50 & 14 \\
\hline MENEMEN & 1 & $\begin{array}{c}\text { Under } \\
\text { Construction }\end{array}$ & 12,5 & 5 \\
\hline ÖDEMIŞ & 1 & $\begin{array}{c}\text { Under } \\
\text { Construction }\end{array}$ & 5 & 2 \\
\hline SEFERIHIISAR & 3 & In Operation & 54 & 26 \\
\hline SELÇUK & 1 & In Operation & 10 & 5 \\
\hline SELÇUK & 1 & $\begin{array}{c}\text { Under } \\
\text { Construction }\end{array}$ & 12 & 5 \\
\hline TİRE & 2 & In Operation & 92 & 36 \\
\hline URLA & 2 & $\begin{array}{c}\text { Under } \\
\text { Construction }\end{array}$ & 19,6 & 8 \\
\hline URLA & 3 & In Operation & 68 & 27 \\
\hline İZMİR & 42 & TOTAL & 1246,375 & 501 \\
\hline
\end{tabular}

Table 1: The location and number of wind power plants installed in Izmir between the years $2008-2018^{58}$

58 "Electricity Market Production Licenses Database", Energy Market Regulatory Authority (EMRA). 
Most of the wind power plants have been implemented according to the former procedures based on the former legislation (Law No. 5346 dated 2005) and regulations (e.g. EIA Directive No. 177 dated 2003). These regulations were composed of less stringent procedures. In the former legislation, there were no criteria for site selection and no requirement for Environmental Impact Assessment (EIA) processes. As a result, wind power projects have received approval regardless of their site selection and have taken generation license easily. Once the legal compliance has been ensured, companies were able to start the installations. Wind power investments, which were passing through such a simple procedure, spread rapidly in specific regions with high wind potential. Rural areas in this sense were exposed to many wind power developments; investors chose sites in rural areas by swiftly completing the entire procedure. Following this, many turbines started to rise on rural landscapes, creating a new spatial configuration.

\section{The Socio-Economic Effects of Energy Policies on Rural Areas}

The case of Turkey, and Izmir in particular, should be evaluated with regard to the effects of neoliberal restructuring of energy policies and should be read as a consequence of the socio-economic/socio-spatial reconfiguration brought about by this restructuring process. In Turkey, spatial transformations have deepened especially after the 2000s, which were mediated directly by the central government. ${ }^{59}$ In this neoliberal period, urbanization practices have been affected by the policies of recentralized state and started to be guided by new forms of collective venture such as public-private partnerships. ${ }^{60}$ Under this neoliberal state-restructuring, planning began to function as a tool to transform not only urban areas but also rural areas, in order to create new sites to be utilized for profit making. In this sense, large-scale energy projects were implemented by the government by means of public-private partnerships. Wind power developments, supported by national and international incentive mechanisms, started to choose location in rural peripheries and this low-carbon energy transition started to manifest itself as the transformation of rural landscapes.

Izmir and its rural periphery have appeared as an important target, since wind power investments in need of vast unbuilt lands prefer rural and natural areas for site selection and the rural periphery of Izmir offers favorable areas in this respect. In a very short period of time, with the help of advantageous procedures and regulations for energy investments, turbines have been installed in close proximity to rural settlements or on agricultural lands and meadows.

59 Kayasü, Serap and Emine Yetişkul, “Evolving Legal and Institutional Frameworks of Neoliberal Urban Policies in Turkey," METU Journal of the Faculty of Architecture 31, no. 2 (2016).

60 Swyngedouw et al., "Neoliberal Urbanization in Europe: Large-Scale Urban Development Projects and the New Urban Policy". 
Consequently, villages and their residents began to be affected negatively from these developments, as they are large-scale in size.

Currently, wind power installations have densely concentrated in rural hinterland of the district. Some of the power plants are located very close to the rural settlements and some of the turbines are installed on environmentally important areas; they are located on meadows, forest lands and farmlands where the main economic activities of villagers take place. ${ }^{61}$ Moreover, the installation of wind power plants requires site clearing, including clearings for power generation structures and distribution systems such as roads, turbines, power lines and substations. ${ }^{62}$ All these interventions generate clear spatial and socio-economic effects on local environments.

Eventually, local oppositions began to emerge when local people faced the negative consequences of rapidly increasing installations. Problems began to occur when private properties were expropriated and together with meadows, they were allocated to investors for wind farm developments (e.g. Bergama, Karaburun). ${ }^{63}$ Agricultural fields, especially olive groves were expropriated (by urgent expropriation) and have been allocated for turbine installation (e.g. Karaburun, Urla, Çeşme). ${ }^{64}$ Peasants in particular began to suffer from the consequences of these developments as the meadows and farmlands have been divided and have turned into energy fields (e.g. Karaburun), ${ }^{65}$ interrupting the pastoral economic activities. Moreover, the installation of turbines resulted in environmental damage both natural and rural due to site clearing for roads and turbine installation (e.g. Urla). ${ }^{66}$ After the construction phase, noise started to affect daily life of people living close to turbines.

Until today, many demonstrations have taken place in protest of these developments. Protests have grown as new installations have been disseminated. Opposition has grown and gained power with the involvement of dissident local platforms and organizations. ${ }^{67}$ Following this, many protests were organized under the leadership of these local initiatives. Villagers also participated in these protests. Later, all the local organizations and platforms came together

61 Özçam, Zeynep, “Rüzgar Enerjisi Çatışması: Kırsal Alanlar ve Rüzgar Enerjisi-Karaburun Deneyimi," Planlama 2018; (Ek 1):15-24.

62 Ülkü Yetiş, Elçin Kentel, Yücel Can Severcan and Ali Türel, “Yenilenebilir Enerji Kaynakları Kullanılarak Elektrik Enerjisi Üretimi ve Bu Konudaki Yasal Çerçevenin Değerlendirilmesi", Unpublished Report Prepared for Muğla Metropolitan Municipality (Ankara: METU-RICBED, 2015).

63 Oppositions in Bergama, Hürriyet, April 2017, accessed January 2018; Oppositions in Bergama, Cumhuriyet, April, 2017, accessed January 2018.

64 Oppositions in Urla. Hürriyet, April 2016, accessed January 2018.

65 Oppositions in Karaburun. Hürriyet, March 2016, accessed January 2018.

66 Oppositions in Urla. Hürriyet, January 2016, accessed January 2018; Oppositions in Urla. Cumhuriyet, January 2016, accessed January 2018.

67 Oppositions Against Wind Energy. Hürriyet, August 2013, accessed November 2016. 
to form an umbrella platform, Rüzgar Yaşamdan Yana Essin Initiative. ${ }^{68}$ This platform was founded in March 2016 by 17 environmentalist organizations, in direct opposition to the wind power developments. The platform includes many environmentalist organizations from the Peninsula (e.g. Urla, Çeşme, Güzelbahçe), from other rural districts of Izmir (e.g. Kemalpaşa, Bayındır, Turgutlu) and from the rest of the Aegean region (e.g. Bodrum, Ayvalık). Protestors have also raised their case through the legal system. The opposing local initiatives together with villagers have launched legal struggle against developments with the help of an organization of environmentalist lawyers (ÇEHAV). Today, the protests against wind power developments have grown and turned into a struggle in the field of energy.

In Turkey, the regulation in planning predominantly rests on strict topdown rules and practices steered by the neoliberal and authoritarian state regulated urban development. ${ }^{69}$ This type of planning practices favors privatized large-scale spatial projects in which private interests override public interest. Similarly, the development processes for wind power are controlled by the authoritarian state regulations where there are limited democratic opportunities for public or voluntary institutions to be included in decision-making processes. These undemocratic conditions brought about the emergence of oppositions. These struggles have become even harder by the increasingly interventionist and authoritarian regime in urban and rural regulation. ${ }^{70}$ In Izmir case, there have been expropriations of agricultural lands and their reallocation to investors for wind farm developments with the intervention of governmental institutions such as Ministry of Energy and Natural Resources, and Ministry of Environment and Urbanization. Criticisms of top-down wind power developments, which bring about important changes to local environment and to daily lives of local communities, are also ascending. In these circumstances, the emergence of such struggles against the government-led wind power developments is inevitable. As Bayırbağ and Penpecioğlu argue, governance practices of capitalist states trying to create new venues for accumulation are the main rationale behind the emergence of protest movements. ${ }^{71}$ Concordantly, the struggle emerged in the field of wind power in Izmir's rural periphery can be regarded as a struggle against neoliberal policies and authoritarian government regulations, which have had detrimental effects on rural environments.

68 Rüzgar Yaşamdan Yana Essin Initiative. Hürriyet, June 2016, accessed November 2016; Rüzgar Yaşamdan Yana Essin Initiative. Cumhuriyet, June 2016, accessed November 2016.

69 Ayda Eraydin and Tuna Taşan-Kok, “State Response to Contemporary Urban Movements in Turkey: A Critical Overview of State Entrepreneurialism and Authoritarian Interventions," Antipode 46, no. 1 (January 2014): 110-129.

70 Ayda Eraydin et. al., "State Response to Contemporary Urban Movements in Turkey".

71 Bayırbağ and Penpecioğlu, “Urban Crisis: 'Limits to Governance of Alienation'”. 

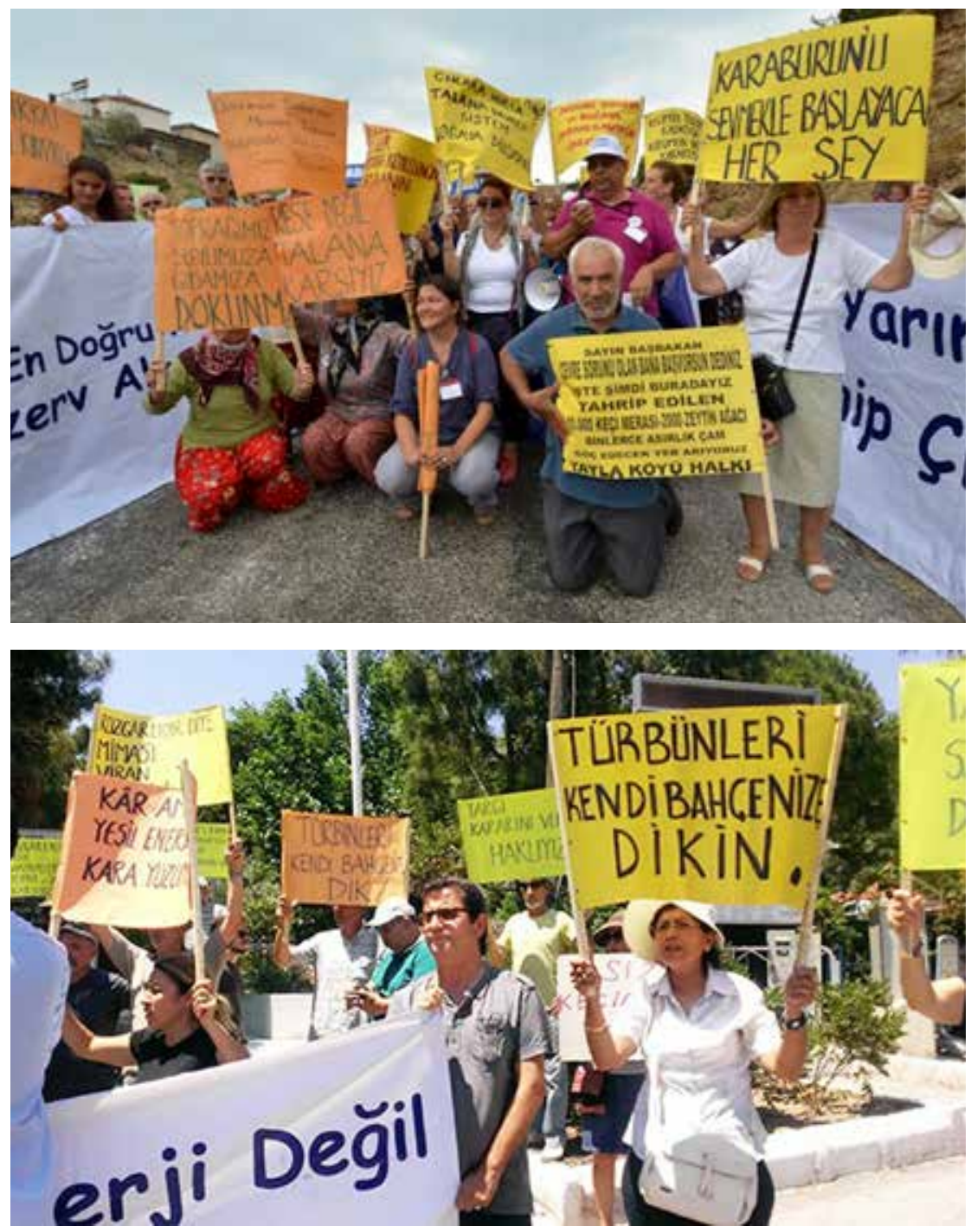

Figure 3 \& 4: Photos from protests against wind power investments held in Karaburun (Source: Karaburun City Council Website, July 2015)

\section{Conclusion}

This paper examines the relation between neoliberal policies and wind power developments as large-scale infrastructural projects taking place in rural peripheries, with a focus on energy policies in Turkey and wind power developments in Izmir. In parallel with the growing global concerns about environmental crisis, the need for a transition to low-carbon energy systems has gained great importance. Consequently, large-scale wind power developments started to increase throughout the world with national and international support sys- 
tems. In Turkey, too, wind power developments have risen over the past few decades, mainly in rural areas. This increase is mainly a result of neoliberal policies in Turkey, which is experienced through the implementation of large-scale projects in both urban and rural areas. However, as these projects are regulated through authoritarian state interventions, oppositions began to emerge as soon as the wind power plants installed in the proximity to the local settlements. The oppositions have rapidly turned into a struggle in the field of energy. This experience shows that, under the neoliberal forces, not only urban land but also rural land is exploited by government mechanisms as a tool for capital accumulation. The emerging protest movements are important, in order to understand the detrimental effects of such large-scale projects on local living environments. As a final remark, these struggles should be read as struggles against global neoliberal policies and their authoritarian state regulations.

\section{References}

Atlı, Buket. "Politics of Renewable Energy Policies in Turkey." Master's Thesis, German Turkish Masters in Social Sciences Humboldt Universität zu Berlin and Middle East Technical University, 2012.

Bayırbağ, Mustafa Kemal and Mehmet Penpecioğlu. "Urban Crisis: 'Limits to Governance of Alienation'." Urban Studies 54, no. 9 (2017): 2056-2071.

Brenner, Neil. “Theses on Urbanization.” Public Culture 25, no. 1 (69) (2013): 85-114.

Brenner, Neil. "Urban Governance and the Production of New State Spaces in Western Europe, 1960-2000." Review of International Political Economy 11, no. 3 (2004): 447-488.

Bridge, Gavin, Stefan Bouzarovski, Michael Bradshaw, and Nick Eyre. "Geographies of Energy Transition: Space, Place and the Low-Carbon Economy." Energy Policy 53 (February 2013): 331-340.

Bridge, Gavin. "Resource Geographies 1: Making Carbon Economies, Old and New." Progress in Human Geography 35, no. 6 (2011): 820-834.

Cavanagh, Connor Joseph and Tor Arve Benjaminsen. "Political Ecology, Variegated Green Economies, and the Foreclosure of Alternative Sustainabilities." Journal of Political Ecology Special Section: Political Ecologies of the Green Economy 24, no. 1 (2017): 200-216.

Devine-Wright, Patrick. "Rethinking NIMBYism: The Role of Place Attachment and Place Identity in Explaining Place-Protective Action." Journal of Community \& Applied Social Psychology 19, no. 6 (November-December 2009): 426-441.

Dincer, Ibrahim. "Renewable Energy and Sustainable Development: A Crucial Review." Renewable and Sustainable Energy Reviews 4, no. 2 (June 2000): 157-175.

Energy Market Regulatory Authority (EMRA). “Electricity Market Production Licenses Database". Accessed June 2019. http://lisans.epdk.org.tr/epvys-web/faces/pages/ lisans/elektrikUretim/elektrikUretimOzetSorgula.xhtml.

Eraydin, Ayda and Tuna Taşan-Kok. "State Response to Contemporary Urban Movements in Turkey: A Critical Overview of State Entrepreneurialism and Authoritarian Interventions." Antipode 46, no. 1 (January 2014): 110-129.

European Commission. "European Commission Sustainable Development". Accessed June 2018. http://ec.europa.eu/environment/eussd/. 
Gipe, Paul. Wind Energy Comes of Age, vol. 4. John Wiley \& Sons, 1995.

Global Wind Energy Council (GWEC). Global Wind Report- 2016. Brussels: Global Wind Energy Association, 2016. Accessed January 2018. http://www.gwec.net/wp-content/ uploads/2017/05/Global-Status-2016.pdf.

International Energy Agency (IEA). "Statistics". Accessed January 2018. http://www.iea. org/statistics/statisticssearch/.

International Energy Agency (IEA). "The IEA Energy Efficiency Indicators Database". Accessed January 2018. https://www.iea.org/newsroom/news/2017/december/theiea-energy-efficiency-indicators-database.html.

International Energy Agency (IEA). Key Trends in CO2 Emissions. Excerpt from:CO2 Emissions from Fuel Combustion. Paris: International Energy Agency, 2015. Accessed January 2018. www.iea.org/publications/freepublications/publication/CO2 EmissionsTrends.pdf.

Kayasü, Serap and Emine Yetişkul. "Evolving Legal and Institutional Frameworks of Neoliberal Urban Policies in Turkey." METU Journal of the Faculty of Architecture 31, no. 2 (2016): 209-222.

Keil, Roger. "The Urban Politics of Roll-With-It Neoliberalization." City 13, no. 2-3 (2009): 230-245.

Matthews, Karine and Matthew Paterson. "Boom or Bust? The Economic Engine Behind the Drive for Climate Change Policy." Global Change, Peace \& Security 17, no. 1 (2005): 59-75.

McLaren Loring, Joyce. "Wind Energy Planning in England, Wales and Denmark: Factors Influencing Project Success." Energy Policy 35, no. 4 (April 2007): 2648-2660.

Ministry of Energy and Natural Resources (MENR). Turkey's National Renewable Energy Action Plan. (Ankara: Ministry of Energy and Natural Resources, 2014). Accessed December 2017. https://www.eie.gov.tr/duyurular_haberler/document/Turkiye_ Ulusal_Yenilenebilir_Enerji_Eylem_Plani.pdf.

Ministry of Foreign Affairs (MFA). "Turkey's Energy Profile and Strategy". Accessed January 2018. www.mfa.gov.tr/turkeys-energy-strategy.en.mfa

Molotch, Harvey. "The Political Economy of Growth Machines." Journal of Urban Affairs 15, no. 1 (March 1993): 29-53.

Naumann, Matthias and Anja Reichert-Schick. "Infrastructure and Peripheralization: Empirical Evidence from North-Eastern Germany." In Peripheralization, ed. A. Fischer-Tahir and M. Naumann, 145-167. Wiesbaden: Springer VS, 2013.

Özçam, Zeynep. “Rüzgar Enerjisi Çatışması: Kırsal Alanlar ve Rüzgar Enerjisi-Karaburun Deneyimi." Planlama 2018; (Ek 1):15-24.

REN21. "Bonn International Conference for Renewable Energy". Accessed January 2018. https://www.ren21.net/events/irecs/.

Swyngedouw, Erik, Frank Moulaert, and Arantxa Rodriguez. "Neoliberal Urbanization in Europe: Large-Scale Urban Development Projects and the New Urban Policy." Antipode 34, no. 3 (July 2002): 542-577.

Tekeli, İlhan and Anlı Ataöv. Sürdürülebilir Toplum ve Yapılı Çevre - StratejilerYelpazesi İstanbul: İstanbul Bilgi ÜniversitesiYayınları, 2017.

The Organisation for Economic Co-operation and Development (OECD). Development Cooperation Report 2017: Data for Development (OECD Publishing, 2018). Accessed January 2018. http://www.oecd.org/dac/stats/turkeys-official-development-assistanceoda.htm. 
Toke, David, Sylvia Breukers, and Maarten Wolsink. "Wind Power Deployment Outcomes: How Can We Account for the Differences?." Renewable and Sustainable Energy Reviews 12, no. 4 (May 2008): 1129-1147.

Turkish Wind Energy Association (TWEA). Turkish Wind Energy Statistics Report - July 2018 (Ankara: Turkish Wind Energy Association, 2017). Accessed December 2018. https://www.tureb.com.tr/files/tureb_sayfa/duyurular/2018/08/istatistik_raporu_ temmuz_2018.pdf.

United Nations. "The Sustainable Development Agenda". Accessed June 2018. https:// www.un.org/sustainabledevelopment/development-agenda/

United Nations. United Nations Sustainable Development. Accessed June 2018. http:// www.un.org/sustainabledevelopment/.

Van der Horst, Dan. “NIMBY or Not? Exploring the Relevance of Location and the Politics of Voiced Opinions in Renewable Energy Siting Controversies." Energy Policy 35, no. 5 (May 2007): 2705-2714.

Wolsink, Maarten. "Planning of Renewables Schemes: Deliberative and Fair Decision-Making on Landscape Issues Instead of Reproachful Accusations of Non-Cooperation." Energy Policy 35, no. 5 (May 2007): 2692-2704.

Woods, Michael. "Conflicting Environmental Visions of the Rural: Windfarm Development in Mid Wales." Sociologia Ruralis 43, no. 3 (July 2003): 271-288.

World Bank. "Renewable Energy Fund for Africa". Accessed January 2018. http://projects. worldbank.org/P160699?lang=en.

Yaniktepe, Bulent, M. Mustafa Savrun, and Tahsin Koroglu. "Current Status of Wind Energy and Wind Energy Policy in Turkey." Energy Conversion and Management 72 (August 2013): 103-110.

Yetiş, Ülkü, Elçin Kentel, Yücel Can Severcan and Ali Türel. "Yenilenebilir Enerji Kaynakları Kullanılarak Elektrik Enerjisi Üretimi ve Bu Konudaki Yasal Çerçevenin Değerlendirilmesi." Unpublished Report Prepared for Muğla Metropolitan Municipality. Ankara: METU-RICBED, 2015.

Zimmerbauer, Kaj and Anssi Paasi. "When Old and New Regionalism Collide: Deinstitutionalization of Regions and Resistance Identity in Municipality Amalgamations." Journal of Rural Studies 30 (April 2013): 31-40. 